\title{
Medieval Approaches to Future Contingents
}

\section{Knuuttila, Simo Jussi lisakki}

2018

Knuuttila, S J I 2018 , ' Medieval Approaches to Future Contingents ', Roczniki Filozoficzne , vol. 66 , no. 4 , pp. 99-114 . https://doi.org/10.18290/rf.2018.66.4-5en

http://hdl.handle.net/10138/285179

https://doi.org/10.18290/rf.2018.66.4-5en

cc_by_nc_nd

publishedVersion

Downloaded from Helda, University of Helsinki institutional repository.

This is an electronic reprint of the original article.

This reprint may differ from the original in pagination and typographic detail.

Please cite the original version. 


\section{SIMO KNUUTTILA}

\section{MEDIEVAL APPROACHES TO FUTURE CONTINGENTS}

I shall address the main lines of medieval approaches to future contingents with the aim of making some remarks on Marcin Tkaczyk's paper "The antinomy of future contingent events." While Tkaczyk discusses some medieval Islamic, Jewish and Christian views in the historical section of his paper, I shall deal with the theories of late scholastic philosophical theology which may be helpful in this context. (This part is partially based on KNUUTTILA 2015). Medieval authors usually held that Aristotle restricted bivalence with respect to future contingent propositions, whereas the doctrine of Divine omniscience demanded Catholic believers to defend universal bivalence. Until the fourteenth century, Scholastic authors thought that God's knowledge of historical events took place outside of temporal order and was not strictly speaking prescience. William Ockham and his followers discussed God's knowledge of future contingent propositions in temporal terms, which makes their discussions more congenial with philosophy. At the end, I shall present some comparisons between these views and the theory of Tkaczyk.

\section{FROM ARISTOTLE TO BOETHIUS}

The discussion of future contingents in Western philosophy derives from Chapter 9 of Aristotle's treatise De interpretatione where it is asked whether predictions such as "There will be a sea battle tomorrow" are true or false, whether they are necessarily true if true, and whether their truth entails that future events are inevitable. Most modern commentators assume that in De

Prof. Simo KnUUtTila - Profesor Emeritus Uniwersytetu Helsińskiego; adres do korespondencji—e-mail: simo.knuuttila@helsinki.fi. 
interpretatione 9 Aristotle aims at avoiding fatalism by restricting bivalence with respect to future contingent predictions (FREDE 1970; GASKIN 1995; Crivelli 2004; WeIdemann 2012). This was also the view of Jan Łukasiewicz who revived the discussion about future contingents in modern philosophical logic. The problems in Łukasiewicz's approach to the antinomy of future contingents are discussed by Marcin Tkaczyk in "The Antinomy of Future Contingent Events." The second interpretation insists that Aristotle does not deny the truth of these statements, but their being true or false in the same way as other statements are true or false. The difference is that while the truth of past, present and other future true statements is necessary, the truth of future contingent statements is not. This interpretation is associated with Aristotle's elaboration of the remark that not everything which is actual and therefore necessary is necessary without qualification (19a 23). Aristotle speaks elsewhere about singular future possibilities which may be realized or remain unrealized and which may or may not cease to be antecedent possibilities. In the same way some predictions may begin to be necessarily true or necessarily false. (See De int. 19 a 13-17; EN III, 5, 1114 a 17-19; Met. VI, 3.) For various versions of the second interpretation without the denial of bivalence, see HinTIKKA 1973; Fine 1984; JUDSON 1988.

Some Stoics read Aristotle in the former way, as Boethius reports in his second commentary on Aristotle's De interpretatione (In Periherm. II, 208, 1-4). Future contingent propositions were held as true or false by the Stoics, who took the universally valid principle of bivalence to imply the predetermination of all future events. (See Cicero, De fato, 20-21; Bobzien 1998, 59-86.) Boethius regarded the Stoic interpretation of Aristotle's view as mistaken, his interpretation being based on the distinction between the terms of definitely true or false and indefinitely true or false. The same terms were also used in Ammonius's commentary. (Ammonius's Greek commentary on De interpretatione 9 is translated by Blank and Boethius's Latin commentaries by Kretzmann in the same volume, with interpretative essays by SoRABJI, KRETZMANN and MignuCCI in 1998.) The contemporary reconstructions of the theory of Ammonius and Boethius can be divided into two groups somewhat similarly as the interpretations of Aristotle. According to one interpretation, Ammonius and Boethius ascribe to Aristotle the view that the predictions of future contingent events and their denials differ from other contradictory pairs because the propositions are neither definitely true nor definitely false, but only indefinitely true or false. In answering the Stoic criticism, Ammonius and Boethius might have hold that future contingent 
propositions have the disjunctive property of being true-or-false, which would mean something other than simply lacking a truth value (FREDE 1985; Craig 1988; Gaskin 1995; Kretzmann 1998). Another interpretation particularly developed by Mignucci $(1988 ; 1998)$ is that future contingent propositions are not definitely true or false because their truth-makers are not yet determined but are indeterminately true or indeterminately false. No qualification of the principle of bivalence is involved. All commentators agree that Ammonius and Boethius assumed that the definite truth of predictions implies determinism and that Aristotle therefore denied such truth of future contingent propositions, but it is not quite clear how they understood the indefinite truth of these. (See also SORABJI 1998.)

The necessity of the present to which Boethius refers can be expressed as follows:

(1) $\forall x\left(\varphi_{\mathrm{t}} x \rightarrow \square_{\mathrm{t}} \varphi_{\mathrm{t}} x\right)$.

Even though statements about things at the present are temporally necessary, these statements as such, without a temporal specification, are contingently true or false if they are about changing things. This was one of Boethius's explanations of what Aristotle meant when he wrote that what is necessarily is when it is, although is not necessary simpliciter (BoETHIUs 1877, 121.20-122.15; Boethius 1880, 241.1-242.15). Aristotle applied the frequency view of necessity and contingency to the truth and falsity of temporally indefinite statements and to things in general in many places. (See, for example, Metaphysics IX, 10 (1051 b 10-17.) According to this paradigm, what always is, is by necessity, and what never is, is impossible. Possibility is interpreted as expressing what is at least sometimes actual. (See Boethius 1877, 124.30-125.14; 200.20-201.3; Boethius 1880, 237.15 ; for the prevalence of temporally indefinite sentence types in ancient philosophy, see HintikKa 1973, Ch. 4; BOBZIEN 1998, 66-67, 100-101, 109-111). Referring to this quasi-statistical approach to modality, Boethius argues that $\varphi_{\mathrm{t}}(\mathrm{a})$ is compatible with the temporally indefinite possibility

(2) $\diamond-\varphi(a)$

which is true if it is not determined that $\varphi(a)$ is always true when a exists. Boethius also refers to antecedent prospective alternatives, arguing that

(3) $\square_{t} \varphi_{t}$ (a)

is compatible with 
(4) $\diamond_{\text {earlier thant }}-\varphi_{\mathrm{t}}(a)$.

See Boethius 1880, 245.4-246.19.

Boethius thinks that there are alternative future possibilities with respect to a certain time, of which those which remain unrealized at that time disappear. Boethius and his later followers did not mean that the idea of diachronic alternatives would qualify the necessity of the present; they thought that prospective alternatives made it compatible with a non-deterministic view of action. It has been argued that Boethius implicitly operates with temporally definite simultaneous alternatives such as

(5) $\diamond_{\mathrm{t}}-\varphi_{\mathrm{t}}(\mathrm{a}) \& \varphi_{\mathrm{t}}(a)$

but this is a surmise based on later developments in medieval logic. (See BORNHOLDT 2017.)

In his Consolatio philosophiae, Boethius argues that God is atemporal and has timeless knowledge of everything. God's knowledge is not foreknowledge, since it is not temporally located, but the predictions of future contingents are true or false from the point of view of God's eternal knowledge of the things referred to (V, 6, 25-32; see also Augustine, City of God $\mathrm{XI}, 21)$. It is necessary that if God knows that $p$, then $p$. This 'conditional necessity' does not imply the 'simple necessity' of $p$ (Consolatio philosophiae V, 6.27-30). Medieval authors commonly thought that the knowledge of $p$ does not make $p$ necessary; see, for example, Anselm of Canterbury in Cur Deus homo 2.17, 125.6-126.2. Boethius's distinction was often read as a modal placement solution to the problem of foreknowledge and free will. Thomas Aquinas, for example, refers to Boethius's distinction using the terms necessitas consequentiae and necessitas consequentis (Summa contra gentiles I, 67). Before Aquinas, Abelard analysed this in terms of the distinction between a modal proposition de sensu and de re, later commonly codified as a distinction between modality in sensu composito and in sensu diviso (Logica 'Ingredientibus' 429.26-430.36; Dialectica 217.27-219.24). This became an influential reading because it was included in the Peter Lombard's theological textbook (see Sententiae I, 38.2).

\section{PETER ABELARD}

Peter Abelard interpreted Aristotle's view of bivalence in the same way as Mignucci did with respect to Boethius, arguing that future contingent 
propositions are true or false, although not determinately or necessarily so. The difference between future contingent propositions and other propositions has nothing to do with a difference with respect to bivalence; it concerns the determinateness or indeterminateness of the truth-makers of propositions. Abelard thought that the central thesis of Chapter 9 of Aristotle's De interpretatione is that of all contradictory pairs of propositions necessarily one part is true and the other false. This does not imply that one is necessarily true and the other necessarily false, although one is true and the other false.In some propositions about past and present states of affairs the truth and falsity depend on future contingents, such as 'Socrates is the name of a man going to eat tomorrow'. The truth and falsity of propositions of this kind are not knowable without knowledge of future contingent states of affairs which are indeterminate and epistemically inaccessible to human beings. Hence these propositions have an indeterminate truth and falsity and do not differ from future contingent propositions in this respect. While propositions are indeterminately true or false if their truth-value depends on indeterminate future contingent states of affairs, the actual inherence of truth in propositions of the form: "Socrates will eat tomorrow' is true" is determinate as a present state of affairs. Abelard also remarks that God knows whether any proposition is true and false, but this supranatural knowability does not make things necessary (Logica 'Ingredientibus' 421-2).

In discussing the necessity of the present, Abelard follows Boethius in stating that what is actual at a certain point of time is necessary in the sense that it can no longer be avoided, but he also argues that unrealized alternatives may be possible at the same time in the sense that they could have happened at that time. The actuality of a contingent state of affairs at a specified future time does not exclude the possibility of simultaneous alternatives, nor does the truth of a proposition about this state of affairs make it necessary (MARTIN 2003). This is the background of Abelard's deviation from Boethius's view of the truth and falsity of future contingent propositions.

In the theological context of timeless divine omniscience, it was natural to treat the statements or their asserted content as non-tensed and temporally definite. After Abelard, this approach was increasingly applied in twelfthcentury, particularly by the authors who were later called nominales. One of the theses of this group was "What is once true is always true." (See IWAKUMA \& EBBESEN 1992, 196, 199-201, 205-6. For the history of the principle, see also MARENBON 1992, 58-61 and EBBESEN 1992, 73-4.) If God's knowledge is described by using tensed statements, analogously to the 
articles of faith before and after the coming of Christ, one should read them so that they signify the same (Peter of Poitiers, Sententiae I, 7, 133-43; I, 12, 199-223; I, 14, 328-53). This became a well-known position, since it was also employed in Peter Lombard's Sententiae (I, 39.1; 41.3). Since God's knowledge about contingent things was regarded as unchangeable, the contingency of this knowledge also implied the denial of the Aristotelian equation of immutability with necessity, a denial regarded as an explicit doctrine of the nominales (EBbesen \& IwAKuma 1992, 194). The new modal paradigm which is more or less consciously applied in these discussions of God's will, power and knowledge could be characterized as the model of simultaneous alternatives.

\section{THOMAS AQUINAS}

The conception of God's eternal and timeless knowledge in Augustine and Boethius became a central issue in Thomas Aquinas. According to him, God knows all combinations of things in particular times simultaneously by one eternal vision. Temporal things are timelessly present to God, who has a direct knowledge of them and their relative temporal order in their actuality, none of them being past or future with respect to His cognition (Sent. I, 38.1.4-5; Summa contra gentiles I, 66; Summa theologiae I, 14.9, 14). Things known by God are necessary by supposition with respect to God's knowledge and providence, but many of them are contingent with respect to their proximate causes (Sent. I, 38.1.5; Summa contra gentiles I, 67; Summa theologiae I, 14.13; De veritate 2.12 ). The ultimate source of the actuality of the created order is the divine will (In Periherm. I, 14, 197). While prophetic predictions of future contingents are possible through a revelatory participation in divine knowledge, their truth remains a supernatural matter (Summa theologiae II-2, 171.3, 6). Speaking about divine prescience is a temporal projection of the divine mode of knowing. For various interpretations of Aquinas's view, see WIPPEL 1985; CRAIG 1988, 103-126; GORIS 1996; MARENBON 2005, 117-162. Later medieval critics found the allegedly Thomist idea of the simultaneous presence of each instant of time to God's nontemporal eternal vision problematic. (See JOHN Duns Scotus, Lectura I, $39.1-5,23,27,85,87)$. 
INTERPRETING ARISTOTLE'S DE INTERPRETATIONE 9

While Abelard thought that the universal validity of the principle of bivalence was defended by Aristotle, thirteenth-century commentators were less sure about Aristotle's position. Albert the Great and Thomas Aquinas stressed that the determinate truth of the contradictory pairs of future contingents did not imply the determinate truth of their members. They regarded this as the main thesis of Chapter 9 of De interpretatione, but did not say that future contingents are true or false, apparently feeling unsure whether Aristotle would have counted indeterminately true statements as true (ALBert the Great, Liber Perihermeneias, I, 5.4-6; Thomas Aquinas, In Peri herm. I, 13-15). This was a step towards limited bivalence in interpreting Aristotle, some form of which was also defended by the Arabic commentators Abū Nasr al-Fārābīand Averroes (See Al-Farabi's Commentary and Short Treatise on Aristotle's De interpretatione, trans. Frederick W. Zimmermann, lxviii, 75-79, 91-92, 244-5, and Averroes's Middle Commentary on Aristotle's De interpretatione, trans. Ali Benmakhlouf and Stéphane Diebler, 103-108). Among Latin authors this interpretation of Aristotle was explicitly put forward by some later commentators such as Walter Burley (Commentarius in librum Perihermeneias Aristotelis, ed. S. Brown, 92, 956), William Ockham (Expositio in Librum Perihermenias Aristotelis I, 6.15), Peter Auriol (Sent. I, 38.3, 817-28), Gregory of Rimini (Sent. I, 38. 1.1 (238-43) and Peter of Ailly (Quaestiones super Sent. I, 11.1A). John Buridan read Aristotle in the same way as Abelard. All assertoric statements are true or false though those about future contingents are not determinately true or false (Questiones longe super librum Perihermeneias I,10). Since theologians usually thought that divine omniscience presupposed bivalence, the discussion of future contingents was divided into historical constructions of Aristotle's view and the systematic discussions in theology which usually followed the Abelardian lines.

\section{LATER MEDIEVAL VIEWS}

The most influential late medieval approach to future contingents was based on John Duns Scotus's modal theory which shows intuitive similarities with some features of the contemporary possible-worlds semantics. In the Augustinian tradition metaphysical possibilities were ultimately based on 
the divine essence and represented the ways in which it could be imitated by created things. According to Scotus, when God as an omniscient being knows all possibilities, he does not know them by turning first to his essence. Possibilities can be known in themselves; in fact, they would be what they are even if there were no God. Scotus calls the propositional formulations of pure possibilities logical possibilities (possibile logicum). These express things and states of affairs to which it is not repugnant to be. Possibilities as such have no kind of existence of their own but are real in the sense that they form the precondition for everything that is or can be. Scotus takes it as an obvious fact that there are contingent states of affairs which in his view could have not been at that very moment of time at which they are. This idea of simultaneous alternatives differed from the traditional view of the necessity of the present and the extensional frequency models of modality. Scotus argues that that if the acts of the first cause are necessary, there is no genuine contingency in the world. In his metaphysics, all constituents of the created world are metaphysically contingent. (For Scotus's modal theory, see Vos et al. 1994; KnUUtTILa 1996; Normore 2003; HonNeFELDER 2005.)

God's omniscience involves all possibilities and, as objects of God's knowledge, they receive intelligible or objective being. Some of these are included in God's providential plan of creation and will receive actual being. The description of a possible world at a certain moment consists of compossible possibilities. Since all finite beings are contingently actual, alternative possibilities are possible with respect to the same time, though they are not compossible with what is actual. According to Scotus, impossibilities are incompossibilities between possible ingredients, such as Socrates's sitting at a certain time and Socrates's not sitting at that same time. God could have chosen a world in which the first happens by Socrates's free will or a world in which the second happens by Socrates's free will. Since these possibilities are real possibilities, though not compossible, they are Socrates's possibilities in alternative histories and form the structure of future contingents (Lect. I, 39.15, 62-63; Ord. I, 35.32.49-51; I, 36.60-61; I, 43.5-7.14). Scotus's modal metaphysics incorporates many ideas from the early medieval model which was developed by Abelard and the nominales, such as the denial of the necessity of the present, the distinction between immutability and necessity and the universal validity of bivalence. The systematic account of these themes in Scotus's theory made it the most discussed account of God's knowledge and contingency in late medieval and early modern thought. 
Scotus's famous definition of a contingent act is that it is an act the opposite of which could take place at the very instant of time at which it occurs (Ord. I.2.1.1-2, n. 86). In dealing with the free acts of the will, he says that in addition to this logical potency there is also a real potency which is analysed in the same way (Lect. I.39.1-5, n. 50-51). The will as a free cause does not antecedently lose the power to choose between mutually exclusive alternatives with respect to a future instant of time and has it at that future instant, independently of what its volition then is. William Ockham criticized this conception, arguing that a power which cannot be actualized is not real although counterfactual choices are metaphysically possible. (See Sent. I. 38.1 in Opera theologica, IV, 578, 581; Adams 1987, 1130-6.) Ockham followed Scotus in believing that God's eternal choice could be other than it is, but he criticized the view that God knows future free acts through his acts of the will as their ultimate cause, which he, like some of his contemporaries and later commentators, treats as Scotus's position (Sent. I.38.1, Opera theologica, IV, 582-3). In fact, Scotus's view was not simply this (Frost 2010).

Ockham believed, like Scotus, that future contingent propositions are true or false, that created wills are non-determined free causes and that God knows contingent events such as free choices without their being simultaneously present to God as in Aquinas. (For Ockham's view and the relevant texts, see Adams \& Ketzmann 1983.) While Scotus preferred to distinguish God's eternal knowledge and choice from the temporal order sharply (Lect. I.39.1-2, n. 28, 85; Ord. I, 40, n. 8), Ockham thought that they can, theoretically speaking, be treated as temporally past. This led him to ask how God's foreknowledge as something is compatible with the contingency of the future things since past things are necessary. Ockham's answer shows similarities with Abelard's solution mentioned above: even though God's foreknowledge of a contingent future state of affairs $x$ is past, God's having always known that $x$, his knowing $x$ as a future state of affairs is contingent and does not fall under the necessity of the past. The necessity of the past is connected with the lack of the potency for the opposite which pertains to contingent future things. As long as a contingent future event remains future, it could be different from what an eternally true proposition asserts about it and God's immutable knowledge of this truth could be different as well (Ord. I, 38.1, in Opera theologica, IV, 587; Tractatus de praedestinatione, in Opera philosophica, 515). Many late thinkers embraced this idea. (See WALTer Chatton, Quodlibet 28, trans. in Bornholdt 2017, 337-8, 341-2; 
Robert Holkot, Sent. II, 2 in Seeing the Future Clearly, 127 (a different view in Quodlibet III, 1, ibid. 63); 146; Gregory of Rimini, Sent. I.38.2.3 (302-302); and PIERRE D'AILLY, Quaestiones super Sent. I, 11.3S). This is also the hallmark of what is called the Ockhamist view of divine foreknowledge in the contemporary philosophical theology (ZAGZEBSKI 1991, 66-97).

In the fourteenth century, it was increasingly believed that future contingent statements were neither true nor false in Aristotle. Peter Auriol took this be true also in theology, arguing that because of the lack a truth value, even God is aware of the future in a way which does not imply that future contingent statements are true or false (SCHABEL 2000, 67-123). This was an exceptional view and came to be regarded as heretical when a Papal commission made a decision about the theses of Peter de Rivo, who defended a view similar to that of Auriol, and some of Rivo's statements were then condemned in 1474 by Pope Sixtus VI (BAudry 1950; Schabel 2000 , 315-36).

Ockham's unsolved problem of how God could know the future acts of free will was dealt in the theory of middle knowledge by Luis de Molina (1535-1600). In addition to the knowledge of all metaphysical necessities and possibilities and the chosen possibilities which will be actualized in the providential history, God has a third kind of knowledge (scientia media), which comprises the hypothetical truths about possible beings. In creating the world, God knows what possible creatures would do through their free choice in various situations (FredDoso 1988). Molina's 'middle knowledge' theory about counterfactuals of freedom was actively debated in the sixteenth and seventeenth century and has remained a living issue in the philosophy of religion (DEKKER 2000).

\section{SOME COMPARISONS}

The central thesis of Tkaczyk is that the only correct and global solution of the antinomy of future contingents is to revise the usually accepted thesis that every past state of affairs is determined and to accept the weaker thesis: "Every past event which does not represent a contingent event is determined." The non-determined past events are such as past tense statements referring to future contingent events which are contingently true or contingently false as a result of those future contingent events. This is said to be similar to retroactive causation in the sphere of cultural artefacts. Retro- 
active causal connections are discussed in the light of some examples such that the classes begin at the Catholic University of Lublin on 1 October, but the official opening of the academic year takes place on the third Sunday of October. Similarly it is argued that God can have foreknowledge of a future contingent event insofar as his knowledge is an effect of this event, eternally possessed knowledge being a retroactive effect of contingent future events.

Tkaczyk's theory shows some similarity with the general frame of the views of Ockham and Scotus, the difference being that while medieval authors argued for the temporal necessity of the past, Tkaczyk is sceptical of the general validity of this necessity. It is historically interesting that nobody came to put forward this idea in the extensive medieval discussion of future contingents. Ockham thought that it is impossible for human beings to understand the way in which God knows future contingents even though God unquestionably knows them (Ord. I, 38.1 in Opera theologica, IV, 583-4). The difficulty is not in the antecedent truth of future contingent propositions, but in the knowability of the truth of the propositions about the future acts of the will as a free cause. Since the intellect is not a free power, its cognitive acts seem to be essentially dependent on representations of objects, but how can it know that a proposition about an object is true if it is indetermined? Ockham's theological view was that God eternally has an intuitive and immutable knowledge of all possibilities as well as whether they are ever actualized or not (PANACCIO \& Piché 2010). In knowing the truth or falsity of the propositions corresponding to this picture, God can be said to have known yesterday the truth of a proposition referring to a free choice taking place one week later. The content of God's past knowledge attitude remains contingent before the free choice takes place because God's knowledge could be different similarly as the truth-value of the proposition.

Ockham's future-dependence approach differs from Thaczyk's qualification of the necessity of the past since Ockham regards present and past tense propositions about future contingent events as being only superficially about the past or the present. However, this is not the main point because Ockham discussed the knowledge of such propositions themselves as past facts. The point of issue is that while Ockham held that no past or present thing follows from future things as an effect follows from its cause, this causal link is defended by Thaczyk. Even though Ockham might have been interested in some new light of this kind on the mysterious divine foreknowledge, it should not question his basic theological assumption that created things cannot cause anything in God. Perhaps the dependence could be understood in 
non-causal terms as Scotus did by using the term concomitantia (BORNHOLDT 2017, 112-3), but is the explanation then better than nothing? Later thinkers thought that the doctrine of the scientia media sheds light on this question; perhaps it is easier to understand than the retroactive model which is not contradictory but difficult to imagine, as Thaczyk concludes his paper.

\section{REFERENCES}

\section{PRIMARY SOURCES}

ABŪ NASR AL-FĀRĀBĪ. Al-Farabi's Commentary and Short Treatise on Aristotle's De interpretatione, trans. with introduction and notes by F[rederick] W. Zimmermann. The British Academy Classical and Medieval Logic Texts, 3. Oxford: Oxford University Press, 1981.

Albert the Great. Liber Perihermeneias. In Opera omnia, edited by August Borgnet. Vol. I. Paris: Vivès, 1890.

Ammonius. In Aristotelis De interpretatione commentarius, edited by Adolf Busse. Commentaria in Aristotelem Graeca, 4.5. Berlin: Typis et impensis G. Reimeri, 1897.

- On Aristotle: On Interpretation 9. Translated by David L. Blank, with Boethius, On Aristotle: On Interpretation 9, first and second Commentaries, trans. N. Kretzmann, with Essays by Richard Sorabji, Norman Kretzmann, and Mario Mignucci. London: Duckworth, 1998.

AnSElm OF CANTERbury. Opera omnia. 6 vols, edited by Franciscus Salesius Schmitt. Edinburgh: Nelson, 1946-1961.

ARISTOTLE. Categoriae et Liber de Interpretatione, edited by Lorenzo Minio-Paluello. Oxford: Clarendon Press, 1989.

Ethica Nicomachea, ed. Ingram Bywater. Oxford: Clarendon Press, 1988.

Metaphysics, a revised text with introduction and commentary by William D. Ross. Oxford: Clarendon Press, 1924.

Augustine. De civitate Dei, edited by Bernhard Dombart and Alfons Kalb. (Corpus Christianorum Series Latina, 47-8). Turnhout: Brepols, 1995.

Averroes. Commentaire moyen sur le De interpretatione, trans. with introduction and notes by Ali Benmakhlouf and Stéphane Diebler. Sic et non. Paris: Vrin, 2000.

BAUDRY, Leon (ed.). 1950. La querelle des futures contingents (Louvain 1465-1475). Textes inédits. Paris: Vrin.

Boethius. Commentarii in librum Aristotelis Perihermeneias I-II, edited by Karl Meiser. Leipzig: Teubner, 1877-1880.

Philosophiae consolatio, edited by Ludwig Bieler. Corpus Christianorum Series Latina, 94. Turnhout: Brepols, 1957.

CiCERO. De fato, with an English translation by Harris Rackham. Loeb Classical Library. London: Heinemann, and Cambridge, MA: Harvard University Press, 1968.

Gregory of Rimini. Lectura super Primum at Secundum Sententiarum, edited by Damasus Trapp and Venicio Marcolino. Vol. III. Berlin: de Gruyter, 1984. 
JoHn BURIDAN. Questiones longe super librum Perihermeneias, edited by Ria van der Lecq. (Artistarium, 4). Nijmegen: Ingenium Publishers, 1983.

Peter Abelard. Dialectica, edited by Lambertus Maria de Rijk. Wijsgerige teksten en studies, 1. Assen: van Gorcum, 1956.

Peter Abelards philosophische Schriften I. Die Logica 'Ingredientibus,' edited Bernhard Geyer. Münster: Aschendorff, 1919-27.

Peter Auriol. Scriptum in I Sententiarum, dist. 38-39, edited by Chris Schabel. In "Peter Aureol on Divine Foreknowledge and Future Contingents." Cahiers de l'Institut du moyen-âge grec et latin, Université de Copenhague 65 (1995): 63-212.

Peter of Ailly. Questiones super libros Sententiarum. Strasbourg, 1490.

Peter Lombard. Sententiae in IV libris distinctae, edited PP. Collegium S. Bonaventurae. Grottaferrata: Collegium S. Bonaventurae ad Claras Aquas, 1971-81.

Peter of Poitiers. Sententiae I, ed. Philip S. Moore and Marthe Dulong. (Publications in Medieval Studies, 7). Notre Dame: The University of Notre Dame Press, 1961.

Robert Holкот. Seeing the Future Clearly: Quodlibetal Questions on Future Contingents by Robert Holcot, edited by Paul Streveler and Katherine Tachau with William J. Courtenay and Hester Goodenough Gelber, introduction by Katherine H. Tachau. Toronto: Pontifical Institute of Mediaeval Studies, 1995.

Thomas Aquinas. In libros Aristotelis Peri hermeneias et Posteriorum analyticorum expositio, edited by Raymondo M. Spiazzi. Turin: Marietti, 1964.

Quaestiones disputatae I: De veritate, edited by Raymondo M. Spiazzi. Turin: Marietti, 1964.

- Scriptum super libros Sententiarum, edited by Pierre Mandonnet and Marie-Fabien Moos. 5 vols. Paris: Lethielleux, 1929-56.

- Summa contra gentiles, edited by Ceslao Pera, Pietro Marc, and Pietro Caramello. Turin: Marietti, 1961-67.

- Summa theologiae, edited by Pietro Caramello. Turin: Marietti, 1948-1950.

William Oскнам. Expositio in librum Perihermenias Aristotelis, edited by Angelo Gambatese and Stephen Brown. Opera philosophica II. St. Bonaventure: St. Bonaventure University, 1978.

- Tractatus de praedestinatione et de praescientia Dei respectu fururorum contingentium, edited by Philoteus Boehner and Stephen Brown. (Opera philosophica II). St. Bonaventure: St. Bonaventure University, 1978. Translated in AdAms \& KretzManN 1983.

- Scriptum in Librum primum Sententiarum, dist. 19-48, edited by Girard I. Etzkorn and Francis E. Kelley. Opera theologica IV. St. Bonaventure: St. Bonaventure University, 1979.

Walter Burley. Commentarius in librum Perihermeneias Aristotelis, edited by Stephen Brown in "Walter Burley's Middle Commentary on Aristotle's Peri hermeneias." Franciscan Studies 33 (1973): 42-134.

\section{SECONDARY SOURCES}

Adams, McCord Marilyn, and Norman Kretzmann. 1983. William of Ockham: Predestination, God's Foreknowledge, and Future Contingents. $2^{\text {nd }}$ ed. Indinapolis: Hackett.

Bobzien, Susanne. 1998. Determinism and Freedom in Stoic Philosophy. Oxford: Clarendon Press.

Bornholdt, Jon. 2017. Walter Chatton on Future Contingents: Between Formalism and Ontology. Leiden: Brill. 
CrAIG, William Lane. 1988. The Problem of Divine Foreknowledge and Future Contingents from Aristotle to Suarez. Leiden: Brill.

Crivelli, Paolo. 2004. Aristotle on Truth. Cambridge: Cambridge University Press.

DEKKER, Eef. 2000. Middle Knowledge. Leuven: Peeters.

EBBESEN, Sten. 1992. "What Must One Have an Opinion About." Vivarium 30: 62-79.

FINE, Gail. 1984. "Truth and Necessity in De interpretatione 9." History of Philosophy Quarterly 1: 23-47.

Freddoso, Alfred J. 1988. Luis de Molina, On Divine Foreknowledge, Part IV of the Concordia, trans. with introduction and notes. Ithaca, NY: Cornell University Press.

Frede, Dorothea. 1970. Aristoteles und die 'Seeschlacht'. Das Problem der Contingentia Futura in De Interpretatione 9. Göttingen: Vandenhoeck \& Ruprecht.

GASKIN, Richard. 1995. The Sea Battle and the Master Argument. Berlin: de Gruyter.

Gelber, Hester. 2004. It Could Have Been Otherwise: Contingency and Necessity in Dominican Theology at Oxford 1300-1350. Studien und Texte zur Geistesgeschichte des Mittelalters. Leiden: Brill.

GoRIs, Harm J.M.J. 1996. Free Creatures of an Eternal God. Thomas Aquinas on God's Infallible Foreknowledge and Irresistible Will. Leuven: Peeters.

HinTIKKA, Jaakko. 1973. Time and Necessity: Studies in Aristotle's Theory of Modality. Oxford: Clarendon Press.

HonNEFELDER, Ludger. 2005. Duns Scotus. Munich: Beck.

Iwakuma, Yukio, \& Sten EbBeSEn. 1992. "Logico-Theological Schools from the Second Half of the $12^{\text {th }}$ Century: A List of Sources." Vivarium 30: 173-210.

JudSON, Lindsay. 1988. "La bataille navale d'aujourd'hui: De interpretatione 9." Revue de Philosophie Ancienne 6: 5-37.

KnuUtTILA, Simo. 1993. Modalities in Medieval Philosophy. London, New York: Routledge.

KnUUtTila, Simo. 1996. "Duns Scotus and the Foundations of Logical Modalities." In John Duns Scotus: Metaphysics and Ethics, edited by Lodger Honnefelder, Rega Wood, and Mechthild Dreyer, 127-143. Leiden: Brill.

KnUUtTILA, Simo. 2015, "Medieval Theories of Future Contingents." In Stanford Encyclopedia of Philosophy. Accessed 23.10.2018. https://plato.stanford.edu/entries/medieval-futcont/.

Kretzmann, Norman. 1998. "Boethius and the Truth about Tomorrow's Sea Battle." In AmmOnius, On Aristotle: On Interpretation 9. Translated by David L. Blank, with Boethius, On Aristotle: On Interpretation 9, first and second Commentaries, trans. N. Kretzmann, with Essays by Richard Sorabji, Norman Kretzmann, and Mario Mignucci, 24-52. London: Duckworth.

Marenbon, John. 1992. "Vocalism, Nominalism and the Commentaries on the Categories from the Earlier Twelfth Century." Vivarium 30: 51-61.

MARENBON, John. 2005. Le temps, l'éternité et la prescience de Boète à Thomas d'Aquin. Paris: Vrin.

Martin, Christopher J. 2003. "An Amputee is Bipedal. The Role of the Categories in the Development of Abelard's Theory of Possibility." In La Tradition médiévale des Categories $\left(X I I^{e}-X I V^{e}\right.$ siècles, edited by Joël Biard and Irène Rosier-Catach, 225-242. Éditions de l'Institut Supérieur de Philosophie, Louvain, Paris: Peeters.

MignuCCI, Mario. 1988. "Truth and Modality in Late Antiquity: Boethius on Future Contingent Propositions." In Atti del convegno Internazionale di Storia della Logica. Le Teorie delle Modalità, edited by Giovanna Corsi, Corrado Mangione, and Massimo MugnAI, 47-78. Bologna: CLUEB. 
MignucCi, Mario. 1998. “Ammonius' Sea Battle.” In Ammonius, On Aristotle: On Interpretation 9. Translated by David L. Blank, with Boethius, On Aristotle: On Interpretation 9, first and second Commentaries, trans. N. Kretzmann, with Essays by Richard Sorabji, Norman Kretzmann, and Mario Mignucci, 53-86. London: Duckworth.

Normore, Calvin G. 2003. "Scotus's Modal Theory." In The Cambridge Companion to Duns Scotus, edited by Thomas Williams, 129-160. Cambridge: Cambridge University Press.

PANACCIO, Claude, \& David PichÉ. 2010. "Ockham's Reliabilism and the Intuition of Non-Existents." In Rethinking the History of Skepticism: The Missing Medieval Background, edited by Henrik Lagerlund, 97-118. Leiden: Brill.

Schabel, Chris. 2000. Theology at Paris, 1316-1345: Peter Aureol and the Problem of Divine Foreknowledge and Future Contingents. Aldershot: Ashgate.

SORABJI, Richard. 1998. "The Tree Deterministic Arguments Opposed by Ammonius." In AmmONIUS, On Aristotle: On Interpretation 9. Translated by David L. Blank, with Boethius, On Aristotle: On Interpretation 9, first and second Commentaries, trans. N. Kretzmann, with Essays by Richard Sorabji, Norman Kretzmann, and Mario Mignucci, 3-15. London: Duckworth.

Vos, Antonie, H. Veldhuis, A.H. Looman-Graanskamp, Eef Dekker, N.W. den Bok (1994), John Duns Scotus, Contingency and Freedom. Lectura I.39, trans. with introduction and commentary. The New Synthese Historical Library, 42. Dordrecht: Kluwer Academic Publishers).

Weidemann, Hermann. 1994 (translation and commentaries). Aristoteles, Peri hermeneias. Werke in deutscher Uebersetzung I, 2. Berlin: Akademie-Verlag.

WipPEL, John F. 1985). "Divine Knowledge, Divine Power and Human Freedom in Thomas Aquinas and Henry of Ghent." In Divine Omniscience and Omnipotence in Medieval Philosophy, edited by Tamar Rudavsky, 213-241. Dordrecht: Reidel.

ZagZeBski, Linda. 1991. The Dilemma of Freedom and Foreknowledge. Oxford: Oxford University Press.

\section{MEDIEVAL APPROACHES TO FUTURE CONTINGENTS}

\section{S u m m ary}

This paper discusses the main lines of medieval Latin approaches to future contingents with some remarks on Marcin Tkaczyk's paper "The antinomy of future contingent events." Tkaczyk's theory shows some similarity with the general frame of the views of Ockham and Scotus, the difference being that while medieval authors argued for the temporal necessity of the past, Tkaczyk is sceptical of the general validity of this necessity. Ockham's theological view was that God eternally has an intuitive and immutable knowledge of all possibilities as well as whether they are ever actualized or not (PANACCIO \& PICHÉ 2010). The content of God's past knowledge attitude remains contingent before the free choice takes place because God's knowledge could be different similarly as the truth-value of the proposition. While Ockham held that no past or present thing follows from future things as an effect follows from its cause, this causal link is defended by Tkaczyk. Later thinkers thought that the doctrine of the scientia media sheds light on this question; perhaps it is easier to understand than the retroactive model which is not contradictory but difficult to imagine, as Tkaczyk concludes his paper. 


\title{
ŚREDNIOWIECZNE UJECIA \\ PROBLEMU PRZYSZŁYCH ZDARZEŃ PRZYGODNYCH
}

\author{
Streszczenie
}

Artykuł omawia główne średniowieczne ujęcia zagadnienia przyszłych zdarzeń przygodnych (futura contingentia) z kilkoma uwagami na temat artykułu Marcina Tkaczyka „The antinomy of future contingent events” [„Antynomia przyszłych zdarzeń przygodnych”]. Podejście Tkaczyka wykazuje pewne podobieństwo do ogólnego obrazu poglądów Ockhama i Dunsa Szkota, z tą różnicą, że chociaż średniowieczni autorzy argumentowali za czasową koniecznością przeszłości, Tkaczyk jest sceptyczny wobec ogólej obowiązywalności tej konieczności. Zgodnie z poglądami teologicznymi Ockhama Bóg wiecznie posiada intuicyjną i niezmienną wiedzę o wszystkich możliwościach, a także o tym, czy zostaną one kiedykolwiek zaktualizowane, czy też nie (PANACCIO \& PiCHÉ 2010). Treść przedwiedzy Boga pozostaje przygodna, zanim dokona się wolny wybór, ponieważ wiedza Boga może być inna, podobnie jak wartość logiczna zdania dotyczącego tego wyboru. Podczas gdy Ockham utrzymywał, że zdarzenia przyszłe nie pociągają przeszłych ani teraźniejszych, jak przyczyna pociąga skutek, Tkaczyk broni takiego związku przyczynowego. Późniejsi myśliciele sądzili, że światło na tę kwestię rzuca doktryna scientia media; być może jest ona łatwiejsza do zrozumienia niż model retroaktywny, który — jak konkulduje Tkaczyk w swoim artykule — choć nie jest sprzeczny, jest trudny do wyobrażenia.

Key words: future contingents; scientia media; Boethius; Abelard; Aquinas; Scotus; Ockham.

Slowa kluczowe: przyszłe zdarzenia przygodne; scientia media; Boecjusz; Abelard; Akwinata; Duns Szkot; Ockham.

Information about Author: Prof. Simo KnUUtTILA - Profesor Emeritus of the University of Helsinki; address for correspondence-e-mail: simo.knuuttila@helsinki.fi

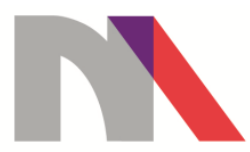

The preparation of the English version of Roczniki Filozoficzne (Annals of Philosophy) and its publication in electronic databases was financed under contract no. 753/P-DUN/2017 from the resources of the Minister of Science and Higher Education for the popularization of science. 